Article

\title{
Performance of Riverbank Filtration under Hydrogeologic Conditions along the Upper Krishna River in Southern India
}

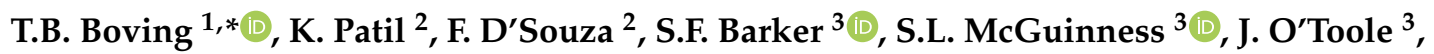 \\ M. Sinclair ${ }^{3}$, A.B. Forbes ${ }^{3}$ and K. Leder ${ }^{3}$ \\ 1 Department of Geosciences, Department of Civil and Environmental Engineering, University of Rhode \\ Island, Kingston, RI 02881, USA \\ 2 The Energy and Resources Institute (TERI), Goa 403202, India; kavitah@teri.res.in (K.P.); \\ fraddry.dsouza@teri.res.in (F.D.) \\ 3 School of Public Health and Preventive Medicine, Monash University, Melbourne, Victoria 3004, Australia; \\ fiona.barker@monash.edu (S.F.B.); sarah.mcguinness@monash.edu (S.L.M.); \\ joanne.otoole@monash.edu (J.O.); martha.sinclair@monash.edu (M.S.); andrew.forbes@monash.edu (A.B.F.); \\ karin.leder@monash.edu (K.L.) \\ * Correspondence: boving@uri.edu; Tel.: +1-401-874-7053; Fax: +1-401-874-2195
}

Received: 10 November 2018; Accepted: 13 December 2018; Published: 21 December 2018

\begin{abstract}
Riverbank filtration (RBF) systems were installed in four rural villages along a $64 \mathrm{~km}$ stretch of the upper Krishna River in southern India; with each one designed to supply approximately 2500 people. Site selection criteria included hydrogeological suitability, land availability and access, proximity to villages and their population sizes, and electric power supply. Water samples were collected from the river and the RBF wells over more than one year (November 2015 to December 2017) and were analyzed for Escherichia coli bacteria, major ions, and a range of other physicochemical and chemical parameters. The shallow groundwater at the study sites was also sampled, but less frequently. The hydrogeology of the four RBF systems was described in terms of bore-log data, mixing of river and groundwater, pumping test data, and vertical water column profiling. E. coli removal percentages of $>99.9 \%$ were observed immediately before and during the monsoon, when E. coli concentrations in the river were the highest. The results provide evidence that RBF installations are challenging but possible under the climate and hydrogeologic conditions prevailing in this part of southern India. Specifically, when installing RBF wells in the study, area one needs to balance the well depth and set-back distance from the river against the limited extent of alluvial deposits. The viability of RBF systems as a domestic water source is also influenced by other factors that are not limited to southern India, including surface water and groundwater salinity, agricultural practices surrounding RBF wells, and the reliability of the power grid.
\end{abstract}

Keywords: riverbank filtration (RBF); Krishna River; southern India; water treatment; water quality; salinity

\section{Introduction}

Access to safe drinking water is essential to human health, but affordable and sustainable solutions remain out of the reach of many communities, particularly in rural areas of developing countries, such as India. Despite India being ranked among the top ten water rich countries with $4 \%$ of the world's fresh water resources, access to fresh water in the world's second most populous nation is problematic [1,2]. Water availability in India is highly variable spatially and temporally, and it is strongly influenced by the southwest monsoon. Coupled with widespread pollution of both surface- 
and groundwater resources, the people of India increasingly face water shortages and water borne disease outbreaks [3]. Herein, an affordable and sustainable water treatment approach to produce water suitable for domestic use is presented.

While India's urban citizens typically have access to improved water sources and sanitation facilities, several hundred million people in rural areas still cannot access adequate water supplies for sanitation and consumption [4,5]. Rural villages typically receive a mixture of public and/or private water supplies, mainly from groundwater wells, piped, or, if available, truck-delivered. For those living in close proximity to a surface water body, river and/or lake water may provide a significant proportion of water for domestic uses, including for drinking. Groundwater supplies are vulnerable to chemical contamination due to geological formations and leaching, as well as microbiological contamination that is associated with subsurface infiltration and/or surface runoff entering the well, notably occurring with shallow aquifers. River water supplies are prone to contamination with industrial wastewater and human-derived effluent, resulting in both chemical and microbiological contamination.

While effective drinking water treatment options exist, such as reverse osmosis systems, these are typically out of the reach of the rural poor, and there remains a need for affordable and sustainable water treatment solutions. One such technology is Riverbank Filtration (RBF), which has been used in Europe for over 100 years [6,7]. In RBF systems, water is withdrawn from one or more wells near a river. Wells may either be vertical or horizontal and are typically installed at least $50 \mathrm{~m}$ away from the river [8]. Pumping a RBF well lowers the water table and river water, together with some groundwater from the land-side, is induced to flow through porous riverbed (alluvial) sediments [9]. As raw surface water travels towards the RBF well, pathogens and suspended contaminants are removed or significantly reduced via a combination of physical, chemical, and biological processes [6]. Bacterial pathogen removal efficiencies of $>99.9 \%$ can be achieved and heavy metal concentrations are reduced [10-12]. When compared to direct surface water abstraction, a disadvantage of RBF could be an increase in salinity or hardness due to the dissolution of minerals in the aquifer or mixing with brackish groundwater.

RBF technology relies on natural, auto-regenerative treatment processes, so properly engineered RBF systems can essentially remain indefinitely effective. Also, the depth to groundwater in the vicinity of rivers is relatively shallow in most areas, which generally makes RBF wells located near rivers less costly to drill and highly productive [6,13]. For these reasons, RBF technology is well suited for use in both developing and industrial countries [10,13,14].

When compared to the north of the country, there are limited data available about the performance of RBF in southern India [10,15], where the climate and hydrogeological conditions along most major rivers are generally less favorable for RBF. This is because the lower amounts of annual precipitation east of the Western Ghats Mountains and the absence of snow melt [16] cause some rivers to flow intermittently or exhibit large stage fluctuations. Also, groundwater salinity levels tend to increase toward south India and the country's arid western states [17]. Therefore, installing RBF systems under the conditions prevailing in southern India poses unique, but little studied challenges. This paper, one of the few reports documenting RBF performance under conditions that are frequently encountered in southern India, highlights some of these challenges. The water quality and hydrogeologic data presented herein and a description of experiences with operating RBF under conditions frequently encountered in southern India contribute to an enhanced understanding of the performance of RBF outside the well-researched locations in northern India. The results of this study might be of interest to water supply authorities and regulators seeking inexpensive water treatment solutions for villages that are in close proximity to surface water bodies without current access to public/private water supply system. 


\section{Materials and Methods}

\subsection{Study Area}

The study was carried out in the Athani Taluka, Belagavi district, in northwestern Karnataka, India (Figure 1). According to the 2011 census [18], the total population of the Taluka is 525,832 and the population density is $120 / \mathrm{km}^{2}$. Agriculture is the main occupation, with sugar cane being the main commercial crop. Approximately $94 \%$ of the geographical area of the Athani Taluka $(199,500$ ha) is under irrigation [19]. During several field visits in 2015, four villages were identified as suitable from a hydrogeological perspective for RBF well installation. The maximum distance between these four sites is $64 \mathrm{~km}$ of river length. The four study locations (Village 1 through 4 ) along the Krishna River are illustrated in Figure 1.

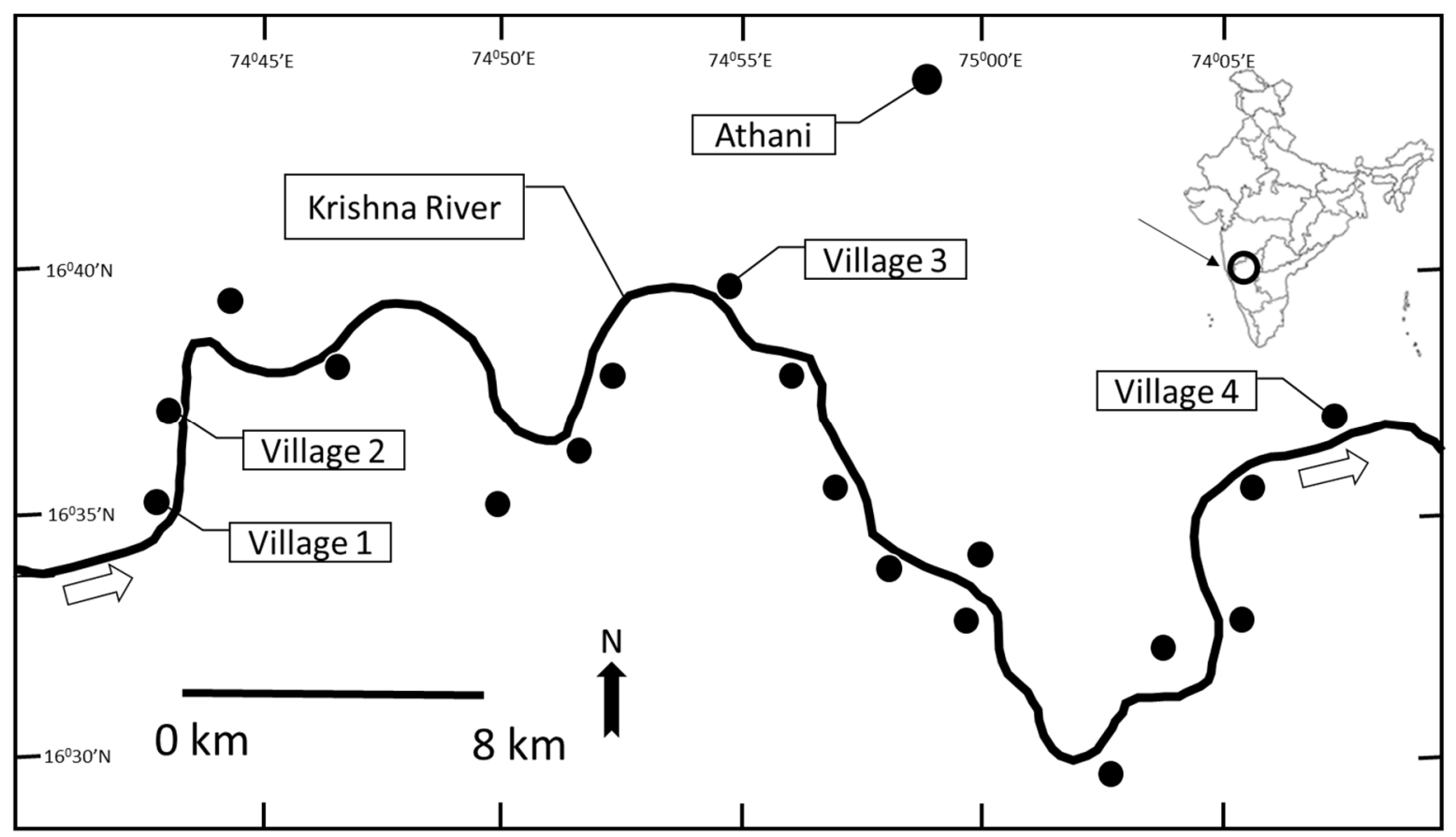

Figure 1. Location of the four villages served by Riverbank Filtration (RBF) water. All villages are located along the Krishna River near Athani in the northwestern part of the state of Karnataka, India. River flow direction indicated by arrows. • Villages.

The study area is part of the Krishna river basin, which is India's fourth largest, spreading across $7.9 \%$ of its surface area. The river Krishna, along with its tributaries Ghataprabha and Malaprabha, is perennial and it flows in an easterly direction. Flow in the river is dominated by the southwest monsoon climate, which induces large inter-seasonal variations in the river stage. In addition, river water flow outside of the monsoon season is dependent upon water releases from dams located upstream of the study area. The climate in the study area is semi-arid. Most of the mean annual rainfall $(582 \mathrm{~mm})$ is received during the period June to October. May is typically the hottest month, with temperatures exceeding $39^{\circ} \mathrm{C}$.

Geologically, the area is dominated by the Basalt of the Tertiary Deccan Trap formation. At depth, leached alumina clay is found on top of the weathered massive trap. At the surface, the basaltic bedrock is predominantly weathered to Vertisol, known in India as Black Cotton Soil. The soil cover in the area ranges in thickness from zero to $25 \mathrm{~m}$ and it is generally fine grained and has a low porosity but permits the percolation of rainwater to the deep bedrock [19]. Alluvial deposits along the Krishna River are limited in extent and thickness. Composed of coarse sand, sandy-loam, and loams, these sediments have good infiltration characteristics [20]. 
Deccan basalt is the primary, multilayer aquifer having low to medium permeability [21]. Intra-trap red bole beds act locally as aquicludes. Shallow unconfined aquifers comprised of unconsolidated deposits above the bedrock are exploited locally. Groundwater occurrence in the Deccan basalt is generally controlled by secondary porosity and it occurs under mostly confined and semi-confined conditions. There are about 2750 borewells and 14,676 dugwells reported in the Athani Taluka [20]. Borewells are usually $40 \mathrm{~m}$ to $175 \mathrm{~m}$ deep, with yields ranging from 40 to $1440 \mathrm{~m}^{3}$ /day. Water level fluctuations of $5 \mathrm{~m}$ to $10 \mathrm{~m}$ are common as river stages fluctuate between seasons. The main source of recharge to all aquifers is precipitation and water applied for irrigation [19]. In the Athani Taluka, the annual recharge is in the range of $100 \mathrm{~mm}$ to $150 \mathrm{~mm}$ [20].

\subsection{Site Selection}

The upper Krishna River watershed was selected for this study because it shares many characteristics of southern India's many polluted rivers [22,23]. That is, local sewage treatment plants, where present, are typically working beyond capacity, so most wastewater is discharged into the river untreated. Also, open defecation is widely practiced in the predominantly rural watershed, resulting in the entry of high levels of human faecal runoff into the river [24]. In addition, most rural villages in the study area lack public water treatment facilities, resulting in villagers abstracting untreated water for domestic use directly from the river or relying on shallow dugwells or handpumps. The study sites were selected based on several criteria, including (1) similar village sizes ( 2500 people), (2) community receptiveness to installation of RBF systems, (3) use of untreated river water as a primary source of drinking water, (4) availability of suitable land close to the river $(<100 \mathrm{~m})$ for RBF well drilling, (5) proximity of RBF wells to villages to limit pipeline construction, and (6) access to electric power lines.

Prior to drilling, a geophysical survey (Schlumberger geoelectric method) was conducted at potential sites with permission for drilling being granted by the District Groundwater Office, Belagavi, India. In addition, data on water quality and quantity were reviewed [19-21,25].

\subsection{Well Construction}

Besides a number of exploration wells, six RBF wells were installed at the four villages (Table 1). All RBF wells were drilled by the rotary air drilling method to a diameter of 10 inches $(25 \mathrm{~cm})$ and cased with 8 inch $(20 \mathrm{~cm})$ PVC pipe, inserted at least $1 \mathrm{~m}$ into the bedrock. Below that level (well sump), the well diameter was 7.5 inches $(19 \mathrm{~cm})$. Pipes were slotted in the field, using $3 \mathrm{~mm}$ slot cutters. The slotted sections, ranging from $7.7 \mathrm{~m}$ to $9.2 \mathrm{~m}$ in length, were set at the contact of the bedrock and the unconsolidated sediments above (Table 1). Solid PVC pipe was used for the remaining length to the surface. Drill cuttings filled the angular space between the pipe and the borehole wall, except for the uppermost $1 \mathrm{~m}$ where either bentonite or concrete was used to minimize infiltration from the surface. The top of each well was set at about $0.6 \mathrm{~m}$ above surface, capped, and protected with a $1 \mathrm{~m}$ by $1 \mathrm{~m}$ concrete foundation and a metal cage (Figure S1). Depending on the well yield, 5 HP or 7.5 HP electric pumps were installed, together with flow meters, designated sampling ports, and water level loggers (Solinst, Georgetown, ON, Canada). All wells were disinfected immediately after drilling following the American Water Works Association standard procedures [26] amended with information from the Washington Department of Health [27]. As needed, disinfection procedures were repeated either after flooding of the well field during monsoon and/or after major pump maintenance.

\subsection{Water Sampling and Analysis}

Between November 2015 to January 2018, water samples were collected from each RBF well field and the adjacent Krishna River at each of the four villages. Measured weekly, the field parameters $\mathrm{pH}$, electrical conductivity (EC), dissolved oxygen (DO), and temperature were determined with calibrated hand-held digital meters (Hanna pH-HI98128, EC-HI983003; DO-HI9146-04, Hanna Instruments, Woonsocket, RI, USA). Turbidity was measured with a Hanna HI98703 instrument. Samples for E. coli 
bacteria were collected in sterile plastic bottles, stored in coolers during transport, and analyzed within 12 to $24 \mathrm{~h}$ in a field laboratory that was set-up in Athani for the duration of this study. In the field lab, the U.S. EPA approved IDEXX Colilert-18 method [28] was used to quantify E. coli bacteria. All bacterial data were reported as Most Probable Number (MPN per $100 \mathrm{~mL}$ ). Duplicate and negative control samples were analyzed for quality assurance. For E. coli data, non-detects were set equal to $0.5 \mathrm{MPN} / 100 \mathrm{~mL}$ to permit graphing on a logarithmic scale [29].

On a monthly basis, a commercial laboratory was used to analyze river and RBF water for major cations $(\mathrm{Na}, \mathrm{K}, \mathrm{Ca}, \mathrm{Mg})$ and anions $\left(\mathrm{Cl}, \mathrm{SO}_{4}, \mathrm{NO}_{3}, \mathrm{~F}, \mathrm{HCO}_{3}, \mathrm{CO}_{3}\right)$, the parameters $\mathrm{NO}_{2}, \mathrm{PO}_{4}$, $\mathrm{B}$, and dissolved silica $\mathrm{SiO}_{2}$, as well as Total Organic Carbon (TOC), Total Dissolved Solids (TDS), Total Suspended Solids (TSS), Biological Oxygen Demand (BOD) and Chemical Oxygen Demand (COD), total alkalinity, and hardness. Groundwater data was collected on two occasions in December 2017 and February 2018 and was analyzed for the same parameters as river and RBF water. The laboratory followed the Bureau of Indian Standards (BIS) IS 3025 (Part 45) Method of Sampling and Test (Physical and Chemical) for Water and Wastewater (First Revision) or the American Public Health Association (APHA) Standard Methods for the Examination of Wastewater (see Table S1 for details). Where appropriate, the results were related to the drinking water limits of the Bureau of Indian Standards [30] (Table S2). The heavy metal and pesticide data that were collected as part of this study are not presented herein.

\section{Results and Discussion}

\subsection{RBF Settings}

The geology encountered during drilling of the RBF wells consisted of bedrock between $15.4 \mathrm{~m}$ and $20.8 \mathrm{~m}$ (Table 1) and unconsolidated sediment above it. The sediment was weathered, silty to sandy silt Black Cotton soil (Vertisol). In villages 3 and 4, alluvial sediments consisting of sand and fine gravel were encountered in discontinuous layers that were no more than $2.5 \mathrm{~m}$ thick. In villages 1 and 2, water-bearing, more silty sediments dominated at the contact with the bedrock. A geologic profile, including well construction information, is shown in Figure S2.

Table 1. RBF well characteristics.

\begin{tabular}{|c|c|c|c|c|c|c|c|c|c|c|}
\hline \multirow[b]{2}{*}{ Location } & \multirow{2}{*}{$\begin{array}{l}\text { Water } \\
\text { Table } \\
\text { (mbgl) }\end{array}$} & \multirow{2}{*}{$\begin{array}{c}\text { Depth } \\
\text { Bedrock } \\
\text { (mbgl) }\end{array}$} & \multicolumn{3}{|c|}{ RBF Well 1} & \multicolumn{3}{|c|}{ RBF Well 2} & \multirow{2}{*}{$\begin{array}{l}\text { Total } \\
\text { Yield } \\
\left(\mathrm{m}^{3} / \mathrm{h}\right)\end{array}$} & \multirow{2}{*}{ Lpcd } \\
\hline & & & $\begin{array}{l}\text { Depth } \\
\text { (m) }\end{array}$ & $\mathrm{L}(\mathrm{m})$ & $\begin{array}{l}\text { Yield } \\
\left(\mathrm{m}^{3} / \mathrm{h}\right)\end{array}$ & $\begin{array}{l}\text { Depth } \\
\text { (m) }\end{array}$ & $L(m)$ & $\begin{array}{l}\text { Yield } \\
\left(\mathrm{m}^{3} / \mathrm{h}\right)\end{array}$ & & \\
\hline Village 1 & 11.1 & 19.7 & 30.8 & 22 & 3 & 30.8 & 24 & 4 & 7 & 8 to 16 \\
\hline Village 2 & 8.3 & 20.8 & 30.8 & 30 & 5 & NA & NA & NA & 5 & 14 to 28 \\
\hline Village 3 & 8.3 & 18.5 & 24.6 & 40 & 12 & NA & NA & NA & 12 & 112 \\
\hline Village 4 & 4.6 & 15.4 & 18.5 & 50 & 5 & 24.6 & 25 & 7 & 12 & 15 to 30 \\
\hline
\end{tabular}

RBF well field yields and supply of liters per capita per day (Lpcd) based on duration of daily power supply available ( $24 \mathrm{~h}$ at Village 3. Everywhere else: $6 \mathrm{~h}$, except $3 \mathrm{~h}$ during April to June). Also provided: depth to water table (post monsoon) and bedrock, depth of well, and distance to river (L). All depths are reported in meters below ground level (mbgl). NA: Not applicable.

At all locations, the wells were drilled approximately $5 \mathrm{~m}$ to $11 \mathrm{~m}$ above the post-monsoon river stage. Six RBF wells were installed across the four villages (Table 1). The two wells at Village 1 are discussed together, because the site constraints made it necessary to install them in close proximity ( $2 \mathrm{~m}$ apart). The set-back distance (L) between the river and the RBF wells ranged from $22 \mathrm{~m}$ to $50 \mathrm{~m}$. The depth to the water table ranged from $4.6 \mathrm{~m}$ to $11.0 \mathrm{~m}$, depending on the site (Table 1). During monsoon, water table elevations rose by several meters, mirroring the river stage. For the first time in recent history, the Krishna River dried up in April and May 2016. During that time, the RBF wells still yielded water, which was apparently fed by baseflow. Flooding of the Village 4 well field occurred during the heavier than usual 2016 Monsoon, but not during the following year. In response to the flooding, 
an additional well (RBF2) was drilled at a more protected location about $1 \mathrm{~km}$ downstream. All well locations were surrounded by irrigated agricultural land, with sugar cane being the dominant crop.

Based on the village size ( $2358 \pm 261$ people) and around-the-clock power supply, a RBF well field yield of $5.4 \pm 0.4 \mathrm{~m}^{3} / \mathrm{h}$ would have been sufficient to meet the 55 liters per capita per day (Lpcd) target that was established by the Government of India for rural villages [31]. The measured yields of the four RBF well field locations ranged from $3 \mathrm{~m}^{3} / \mathrm{h}$ to $12 \mathrm{~m}^{3} / \mathrm{h}$ with an average of $6 \mathrm{~m}^{3} / \mathrm{h}$ (Table 1 ). However, only one well field (Village 3 ) received continuous power from the electric grid serving the village. In all other villages, access to power was limited to six hours daily during most of the year and three hours per day during the driest months (April through June). Due to the scheduled power outages, the 55 Lpcd target could not be met at these locations.

\subsection{Water Quality}

The major ion concentration data for the RBF wells $\left(n_{R B F}=46\right)$, the river $\left(n_{\text {River }}=32\right)$ and local groundwater $\left(\mathrm{n}_{\mathrm{GW}}=12\right)$ are presented in Table $\mathrm{S} 3$. The average ion balance error was $8.6 \%$. Because of the elevated ion balance error, the major ion data were regarded as estimates. Data for the field parameters, including E. coli bacteria, are presented in Table $S 4\left(n_{\text {River }}=442\right.$ and $\left.n_{R B F}=320\right)$.

\subsubsection{Groundwater}

Shallow groundwater samples from wells $<36.5 \mathrm{~m}$ deep were collected from local handpumps and borewells $(\mathrm{n}=12)$, except in Village 3, where no wells were accessible (Supplementary Tables S2 and S3). All of the sampled wells were located $180 \mathrm{~m}$ or less land-ward from the RBF well fields. E. coli concentrations were low (non-detects to $2 \mathrm{MPN}$ per $100 \mathrm{~mL}$ ) in Villages 1 and 4, but they ranged from 5 to $17 \mathrm{MPN}$ per $100 \mathrm{~mL}$ in Village 2. The average $\mathrm{pH}$ was $7.8 \pm 0.5$. The measured EC was high in all groundwater wells, with an average of $4906 \mu \mathrm{S} / \mathrm{cm}$. That value was much higher than the $2420 \mu \mathrm{S} / \mathrm{cm}$ average reported by the Government of India [20] for the study area (Athani Taluka) and also outside the range $(1500$ to $3000 \mu \mathrm{S} / \mathrm{cm}$ ) reported by the Central Ground Water Board of Karnataka [21]. However, EC readings were within the range that was reported by Purandara [25]. The highest recoded EC reading $(8692 \mu \mathrm{S} / \mathrm{cm})$ was measured in a shallow (18.3 m deep) exploration well that was drilled in Village 1 . The comparatively high standard deviation $( \pm 1593 \mu \mathrm{S} / \mathrm{cm})$ reflects high spatial and temporal variability in groundwater EC. Turbidity was up to 11.9 NTU (average: 4.4 NTU). Since the tested groundwater wells were not used on regular basis, the turbidity readings were considered to be artificially elevated because of the disturbance that is caused by the sampling. BOD ranged from 0.1 to $2.8 \mathrm{mg} / \mathrm{L}$ (average: $0.7 \mathrm{mg} / \mathrm{L}$ ) and COD from 21.8 to $174.2 \mathrm{mg} / \mathrm{L}$ (average: $58.0 \mathrm{mg} / \mathrm{L}$ ). The highest COD values were measured in Village 4.

High major ion concentrations were recorded in groundwater samples, particularly $\mathrm{Ca}, \mathrm{Mg}, \mathrm{Cl}$, $\mathrm{SO}_{4}$, and $\mathrm{NO}_{3}$ (Table S3). Most concentrations exceeded the BIS permissible drinking water limits (Table S2) and were detected primarily in water samples that were collected from handpumps. High major ion concentrations were also reflected in the recorded total dissolved solids $(3412 \pm 1136 \mathrm{mg} / \mathrm{L}$ ) and total hardness data $(1801 \pm 842 \mathrm{mg} / \mathrm{L})$. Hardness at this level impacts the ability of water to form lather with soap and increases the boiling point of water [32]. Fluoride concentrations above the BIS limits $(1 \mathrm{mg} / \mathrm{L})$ were detected in Village 1 only (1.2 to $1.4 \mathrm{mg} / \mathrm{L}$; Table S3). Overall, the high degree and extent of groundwater salinity in this part of the Krishna River watershed was not well documented prior to this study. The liberal application of fertilizers (particularly $\mathrm{MgSO}_{4}$ ) on sugar cane fields was repeatedly observed, together with a reliance on flood irrigation. Together, these practices likely contributed to high ion concentrations in the local groundwater [33]. High groundwater salinity is a problem that is not unique to this study area, but it is widespread in this part of southern India [21]. 


\subsubsection{River Water}

Across the four study sites, the average $\mathrm{pH}$ was $8.3 \pm 0.4$ and the water temperature was $25 \pm 0.4{ }^{\circ} \mathrm{C}$ (Table S4). The ranges and averages of the EC, turbidity, and E. coli parameters are summarized in Table 2.

Table 2. Electric conductivity (EC), turbidity and E. coli data for RBF and river water samples.

\begin{tabular}{|c|c|c|c|c|c|c|c|}
\hline \multicolumn{8}{|c|}{ River Water } \\
\hline \multicolumn{2}{|c|}{ Parameter } & $\begin{array}{l}\text { Village } 1 \\
(\mathrm{n}=110)\end{array}$ & \multicolumn{2}{|c|}{ Village $2(\mathrm{n}=111)$} & $\begin{array}{l}\text { Village } 3 \\
(\mathrm{n}=109)\end{array}$ & $\begin{array}{l}\text { Village } 4 \\
(\mathrm{n}=112)\end{array}$ & Average \\
\hline \multirow{3}{*}{$\mathrm{EC}(\mu \mathrm{S} / \mathrm{cm})$} & Average & 965 & \multicolumn{2}{|c|}{855} & 1000 & 1440 & \\
\hline & Range & $196-3728$ & \multicolumn{2}{|c|}{ 196-3139 } & $196-2943$ & $177-4905$ & 1065 \\
\hline & SD & 624 & \multicolumn{2}{|c|}{499} & 650 & 939 & \\
\hline \multirow{3}{*}{ Turbidity(NTU) } & Average & 11.5 & \multicolumn{2}{|c|}{9.2} & 11.5 & 13.4 & \\
\hline & Range & $0.5-60$ & \multicolumn{2}{|c|}{$0.7-75$} & $0.4-73$ & $0.3-97$ & 11.5 \\
\hline & $\mathrm{SD}$ & 10 & \multicolumn{2}{|c|}{10} & 12 & 14 & \\
\hline \multirow{3}{*}{$\begin{array}{c}\text { E.coli } \\
\text { (MPN/100 mL) }\end{array}$} & Average & 57.6 & \multirow{3}{*}{\multicolumn{2}{|c|}{$\begin{array}{c}29.0 \\
1-2420 \\
441.4\end{array}$}} & 24.9 & 22.4 & \\
\hline & Range & $0-2851$ & & & 0-1011 & $0-2420$ & 34.2 \\
\hline & $\mathrm{SD}$ & 533.6 & & & 180.4 & 420.6 & \\
\hline \multicolumn{8}{|c|}{ RBF Well Water } \\
\hline \multicolumn{2}{|c|}{ Parameter } & $\begin{array}{l}\text { Village } 1 \\
(\mathrm{n}=60)\end{array}$ & $\begin{array}{l}\text { Village } 2 \\
(\mathrm{n}=86)\end{array}$ & $\begin{array}{l}\text { Village } 3 \\
(\mathrm{n}=76)\end{array}$ & $\begin{array}{c}\text { Village } 4 \\
\text { RBF } 1 \\
(\mathrm{n}=60)\end{array}$ & $\begin{array}{c}\text { Village } 4 \\
\text { RBF } 2 \\
(n=36)\end{array}$ & Average \\
\hline \multirow{3}{*}{$\mathrm{EC}(\mu \mathrm{S} / \mathrm{cm})$} & Average & 2638 & 4506 & 2936 & 2993 & 3357 & \\
\hline & Range & $1903-5337$ & $2236-7710$ & $1687-5297$ & $1765-3924$ & 2590-3885 & 3286 \\
\hline & $\mathrm{SD}$ & 688 & 994 & 555 & 395 & 306 & \\
\hline \multirow{3}{*}{$\begin{array}{l}\text { Turbidity } \\
\text { (NTU) }\end{array}$} & Average & 3.4 & 2.7 & 3.1 & 9.7 & 7.1 & \\
\hline & Range & $0.4-42$ & $0.4-16$ & $0.3-14$ & $0.4-88$ & $0.6-31$ & 5.2 \\
\hline & SD & 0.7 & 3.0 & 3.0 & 13.6 & 7.0 & \\
\hline \multirow{3}{*}{$\begin{array}{c}\text { E.coli } \\
\text { (MPN/100 mL) }\end{array}$} & Average & 0.8 & 0.8 & 0.6 & 0.8 & 0.8 & \multirow{3}{*}{1.5} \\
\hline & Range & $0-22$ & $0-30$ & $0-16$ & $0-30$ & $0-73$ & \\
\hline & SD & 3.3 & 4.6 & 2.6 & 4.6 & 13.5 & \\
\hline
\end{tabular}

EC and turbidity data are reported as averages (arithmetic means) with the ranges and standard deviations (SD). E.coli averages are reported as geometric means. $\mathrm{n}=$ number of samples. Note: One outlier (867 MPN/100 mL) was removed from the Village 3 RBF E. coli data set.

As a representative example, the river water data for Village 3 show that $E$. coli concentrations and turbidity spiked during the monsoon season, whereas EC declined to $<250 \mu \mathrm{S} / \mathrm{cm}$ (Figure $2 \mathrm{~A}$ through Figure 2C). The inflow of raw sewage and sediments, particularly at the start of the rainy season, explains the elevated bacteria and turbidity levels in the river, while dilution by rainwater reduced the river's EC values. Similar observations were reported during a RBF study along the Kali River, Karnataka [10]. Immediately after the monsoon, when entering the dry period, EC increased steadily to values exceeding $2000 \mu \mathrm{S} / \mathrm{cm}$. The highest measured EC $(2943 \mu \mathrm{S} / \mathrm{cm})$ was observed in April and May 2016, when an exceptional drought caused the Krishna river to almost dry out. The BIS limit for turbidity (1 NTU) was consistently exceeded in the river over the observation period. The average BOD and COD were $1.6 \mathrm{mg} / \mathrm{L}$ and $27.6 \mathrm{mg} / \mathrm{L}$, respectively, with the highest concentrations being recorded at Village 4 . The average total hardness was $277 \mathrm{mg} / \mathrm{L}$. 


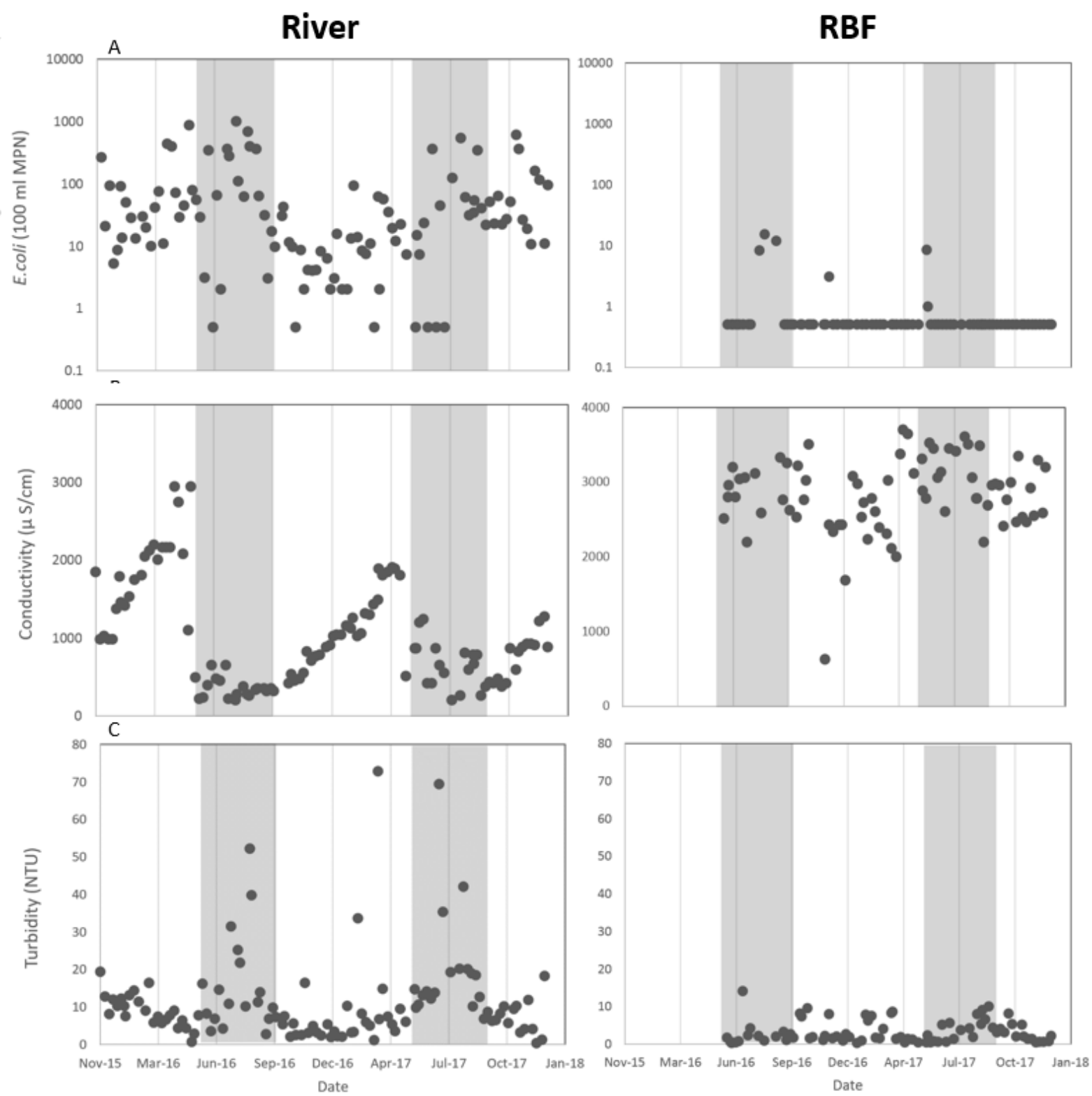

Figure 2. Measurements of (A) E. coli, (B) electrical conductivity, and (C) turbidity in the river (left) and RBF (right) water at Village 3. Shaded areas signify the monsoon season.

In Village 3, the E. coli concentrations in the river water in excess of 1000 MPN per $100 \mathrm{~mL}$ were measured during and immediately after the monsoon. High E. coli concentrations ( $>100$ MPN per $100 \mathrm{~mL}$ ) were also recorded during the pre-monsoon drought (April/May 2016) when only stagnant pools remained in the riverbed. Outside the pre-monsoon and monsoon season, large variations in E.coli counts were noted between sampling events, ranging from non-detects to greater than 500 MPN per $100 \mathrm{~mL}$. Even larger fluctuations, up to $2851 \mathrm{MPN}$ per $100 \mathrm{~mL}$ (Village 1), were recorded in the other three villages. Overall, the annual average of E. coli counts from Krishna River samples that were collected in the study area were comparatively lower (average: 34 MPN per $100 \mathrm{~mL}$; Table 3) than those reported for many other rivers in India. This observation was attributed to the low population density in the watershed $\left(120\right.$ people $\left./ \mathrm{km}^{2}\right)$ relative to northern India, where five-times higher densities are common [10]. 
Table 3. Ranges, averages (arithmetic means), and means of major cation and anion analysis, including dissolved silicate and ion balance in RBF and river water samples. All concentrations are in $\mathrm{mg} / \mathrm{L}$.

\begin{tabular}{|c|c|c|c|c|c|c|c|c|c|c|c|c|}
\hline \multicolumn{13}{|c|}{ RBF Wells } \\
\hline \multirow{2}{*}{ Parameter } & \multicolumn{3}{|c|}{ Village $1(n=9)$} & \multicolumn{3}{|c|}{ Village $2(\mathrm{n}=7)$} & \multicolumn{3}{|c|}{ Village $3(n=15)$} & \multicolumn{3}{|c|}{ Village $4(n=15)$} \\
\hline & Range & Average & SD & Range & Average & SD & Range & Average & SD & Range & Average & SD \\
\hline $\mathrm{Ca}$ & $28.9-60.1$ & 40.3 & 9.7 & $20.8-128.3$ & 67.6 & 35.5 & $24.1-100.2$ & 64.7 & 20.3 & $24.1-216.4$ & 101 & 49.2 \\
\hline $\mathrm{Mg}$ & $36.0-113.8$ & 88.3 & 21.4 & $161.5-367.2$ & 270.3 & 77.2 & $75.4-178.0$ & 117.6 & 26.8 & $26.8-256.8$ & 174.8 & 54.8 \\
\hline $\mathrm{Na}$ & $283.0-363.0$ & 325.8 & 27.5 & $405.5-700.0$ & 535.1 & 92.1 & $179.0-630.0$ & 369 & 101.1 & $182.0-297.0$ & 244.7 & 36.6 \\
\hline $\mathbf{K}$ & $0.8-7.0$ & 3.2 & 1.9 & $0.1-8.0$ & 3.7 & 2.6 & $0.4-6.8$ & 2.9 & 1.6 & $0.3-4.0$ & 1.9 & 0.9 \\
\hline B & 0 & 0 & 0 & 0 & 0 & 0 & 0 & 0 & 0 & 0 & 0 & 0 \\
\hline $\mathrm{HCO}_{3}$ & $424.0-492.0$ & 460 & 23.4 & $252.2-434.0$ & 377.3 & 53.4 & $154.0-447.0$ & 291.1 & 85.1 & $48.0-332.0$ & 218.1 & 87.7 \\
\hline $\mathrm{CO}_{3}$ & $30.0-118.0$ & 70.2 & 23.2 & $10.0-102.0$ & 68 & 31.5 & $10.0-52.0$ & 27.2 & 12.5 & $10-224.0$ & 45 & 72.1 \\
\hline CI & $92.3-564.5$ & 220.1 & 128.02 & $450.9-752.6$ & 569.8 & 105.2 & $230.8-568.0$ & 397.8 & 86.5 & $404.7-699.4$ & 504.1 & 66.8 \\
\hline $\mathrm{SO}_{4}$ & $75.7-343.4$ & 181 & 72.1 & $255.2-996.9$ & 664.9 & 255.2 & $140.8-1209.7$ & 351.4 & 268.3 & $130.0-576.6$ & 240.8 & 113.5 \\
\hline F & $0.4-0.6$ & 0.5 & 0.1 & $0.9-1.0$ & 1 & 0 & $0.2-0.7$ & 0.5 & 0.1 & $0.4-0.6$ & 0.5 & 0.1 \\
\hline $\mathrm{NO}_{3}$ & $13.5-47.8$ & 31.1 & 11.4 & $11.5-35.2$ & 27.3 & 8.1 & $24.5-61.5$ & 44.9 & 10.3 & $33.5-237.5$ & 81.1 & 46.5 \\
\hline $\mathrm{NO}_{2}$ & $0-0.1$ & 0 & 0 & $0-0.1$ & 0 & 0 & $0-0.0$ & 0 & 0 & $0-0.3$ & 0.1 & 0.1 \\
\hline $\mathrm{PO}_{4}$ & $0.1-0.9$ & 9 & 0.2 & $0.7-1.1$ & 0.9 & 0.2 & $0 .-0.3$ & 0.1 & 0.1 & $0-0.2$ & 0.1 & 0.3 \\
\hline $\mathrm{SIO}_{2}$ & $20.7-55.6$ & 38.1 & 13.3 & $28.7-67.3$ & 54.1 & 15.8 & $28.0-94.8$ & 67.2 & 15.1 & $11.7-53.7$ & 36.9 & 11.3 \\
\hline Ion Balance & & $9.0 \%$ & & & $9.0 \%$ & & & $7.9 \%$ & & & $9.3 \%$ & \\
\hline \multicolumn{13}{|c|}{ River Water } \\
\hline \multirow{2}{*}{ Parameter } & \multicolumn{3}{|c|}{ Village $1(n=8)$} & \multicolumn{3}{|c|}{ Village $2(n=8)$} & \multicolumn{3}{|c|}{ Village $3(n=8)$} & \multicolumn{3}{|c|}{ Village $4(n=8)$} \\
\hline & Range & Average & SD & Range & Average & SD & Range & Average & SD & Range & Average & SD \\
\hline $\mathrm{Ca}$ & $14.4-50.3$ & 28.3 & 12.7 & $9.6-48.1$ & 26.8 & 14.3 & $16.0-76.2$ & 35.1 & 20.2 & $19.2-124.3$ & 46.8 & 36.6 \\
\hline $\mathrm{Mg}$ & $2.9-29.2$ & 18.2 & 8.8 & $7.3-46.7$ & 19.6 & 13.2 & $2.3-75.4$ & 23.4 & 21.5 & $3.9-107.0$ & 34.9 & 32.5 \\
\hline $\mathrm{Na}$ & $11.2-114.0$ & 44.2 & 30.8 & $13.0-100.0$ & 44.4 & 28.5 & $11.1-208.0$ & 56.9 & 60.1 & $11.3-326.0$ & 93.5 & 107.0 \\
\hline $\mathbf{K}$ & $1.7-3.6$ & 2.6 & 0.7 & $0.1-12.0$ & 3.2 & 3.5 & $0.8-6.0$ & 2.7 & 1.5 & $0.9-8.0$ & 2.9 & 2.1 \\
\hline B & 0 & 0 & 0 & 0 & 0 & 0 & 0 & 0 & 0 & 0 & 0 & 0 \\
\hline $\mathrm{HCO}_{3}$ & $40.0-146.0$ & 97.9 & 33.7 & $38.8-134.0$ & 92 & 35.3 & $36.0-148.0$ & 89.5 & 37.4 & $42.0-136.0$ & 86.1 & 31.2 \\
\hline $\mathrm{CO}_{3}$ & $10-20.0$ & 11 & 5.5 & $0.1-30.0$ & 12.5 & 9.2 & $0.1-26.0$ & 13 & 10.5 & $0.1-22.0$ & 10.1 & 8.0 \\
\hline CI & $17.8-88.8$ & 49.7 & 24.9 & $14.2-106.5$ & 50.1 & 29.7 & $10.7-234.3$ & 66 & 68.4 & $10.7-447.3$ & 126.9 & 147.9 \\
\hline $\mathrm{SO}_{4}$ & $12.1-98.9$ & 38.3 & 27.2 & $5.6-148.6$ & 39.1 & 43.2 & $7.9-215.0$ & 46.3 & 64.4 & $7.9-343.4$ & 93.1 & 114.4 \\
\hline F & $0.1-0.3$ & 0.3 & 0.2 & $0.1-0.8$ & 0.3 & 0.2 & $0.1-0.7$ & 0.3 & 0.2 & $0-0.9$ & 0.3 & 0.3 \\
\hline $\mathrm{NO}_{3}$ & $1.4-33.4$ & 11.8 & 9.5 & $2.0-15.9$ & 8 & 4.4 & $0.1-14.2$ & 8 & 4.9 & $2.5-14.2$ & 7.2 & 4.6 \\
\hline $\mathrm{NO}_{2}$ & $0-0.1$ & 0 & 0 & $0-0.1$ & 0 & 0 & $0-0.1$ & 0 & 0 & 0 & 0 & 0 \\
\hline $\mathrm{PO}_{4}$ & $0-0.3$ & 0.1 & 0.1 & $0-0.1$ & 0 & 0 & $0-0.3$ & 0.1 & 0.1 & $0-0.1$ & 0 & 0 \\
\hline $\mathrm{SIO}_{2}$ & $0.2-28.7$ & 14 & 7.9 & $4.0-28.9$ & 16.1 & 7.1 & $10.7-27.5$ & 18.7 & 5.8 & $11.5-25.1$ & 17.3 & 4.0 \\
\hline Ion Balance & & $7.7 \%$ & & & $6.9 \%$ & & & $9.3 \%$ & & & $8.3 \%$ & \\
\hline
\end{tabular}


The major ion concentration ranges, averages (arithmetic mean), standard deviation, including ion balance and including dissolved silica, at the four villages are summarized in Table 2. At all four locations, concentrations for $\mathrm{Ca}$ and $\mathrm{Mg}$ exceeded the BIS limits in $17.3 \%$ and $50 \%$ of samples, respectively $(n=52)$. Chloride and $\mathrm{SO}_{4}$ exceedances were less frequent, being $11.5 \%$ and $9.6 \%$, respectively. The $\mathrm{NO}_{3}$ limit was exceeded only once and there were no exceedances for fluoride. Phosphate (as $\mathrm{PO}_{4}$ ) and nitrite $\left(\right.$ as $\mathrm{NO}_{2}$ ) were $<0.4 \mathrm{mg} / \mathrm{L}$ and $<0.1 \mathrm{mg} / \mathrm{L}$, respectively. Boron was found to be below the detection limit of $0.1 \mathrm{mg} / \mathrm{L}$ in all samples.

\subsubsection{RBF Well Water}

Besides chemical and bacteriological measurements, each RBF well that contributed to the water supply of a village was tested for $\mathrm{EC}, \mathrm{pH}$, and temperature. The average E. coli concentration ranged from undetectable to $3.8 \mathrm{MPN}$ per $100 \mathrm{~mL}$ across all four villages (Table 2), with the highest measurement being recorded in Village 4 in the monsoon season (72 MPN per $100 \mathrm{~mL}$ ). A similar spike of E. coli during monsoon was observed in all villages and is also noticeable in Figure 2B. The RBF well reduced peak E. coli concentrations by approximately two orders of magnitude. Beyond these spikes, E. coli concentrations were at or below the detection limit. In general, E. coli removal percentages of $>99.9 \%$ were observed, equivalent to three $\log _{10}$ units immediately before and during the monsoon, when E. coli concentrations in the river where also highest (Figure 2A). Outside the monsoon season, when $E$. coli concentrations in the river water were low ( $<100 \mathrm{MPN}$ per $100 \mathrm{~mL})$, the minimum bacteria removal capacities that could be quantified with our method ranged from $90 \%$ to $99 \%$.

The average EC across all sites was $3821 \mu \mathrm{S} / \mathrm{cm}$ (Table 3); 0.67 times lower than the groundwater (average: $4906 \mu \mathrm{S} / \mathrm{cm}$ ) but 3.1 times higher than the river (Table 2). As the data in Figure 2B indicate, the EC in the RBF water remained elevated during the monsoon and afterwards. The average turbidity was $5.3 \mathrm{NTU}$, which was comparable to the groundwater (4.4 NTU) and approximately half as low as the river (Table 2). Also, as expected, Figure 2C clearly shows that the turbidity spikes observed in the river during monsoon as well as during the dry season were attenuated in the RBF water. The average $\mathrm{pH}$ was 7.7 (Table S4) and the water temperature was $26.4^{\circ} \mathrm{C}$ on average. The BOD (average: $0.8 \mathrm{mg} / \mathrm{L}$ ) of RBF treated water was half that of the river water and was similar to the groundwater. The COD (average: $32.1 \mathrm{mg} / \mathrm{L}$ ) was similar to that of the river and 0.55 times lower than the groundwater. Total hardness (average: $852 \mathrm{mg} / \mathrm{L}$ ) was three times higher than in the river, but was 2.1 times lower than the groundwater. All major ion BIS limits were frequently exceeded at all four villages ( $n=78$; Table S3). Higher then acceptable fluoride concentrations $(>1.0 \mathrm{mg} / \mathrm{L})$ were recorded in a small fraction $(7.7 \%)$ of all samples (up to $1.4 \mathrm{mg} / \mathrm{L}$; Village 2 ).

In terms of major ion concentrations (Table 3), the hydrogeochemical characteristics of the RBF water were closer to that of the shallow groundwater than the river (Figure 3A). However, differences existed between sites (Figure 3B-E). For instance, the composition of the RBF water at Village 2 was very similar to the GW (Figure 3D), except for $\mathrm{Ca}$ and $\mathrm{NO}_{3}$ concentrations, which were both lower in the RBF well water. At Village 4 (Figure 3E), the RBF water was closer in composition to the river water, which suggests that a greater fraction of river water contributed to this RBF well field. 

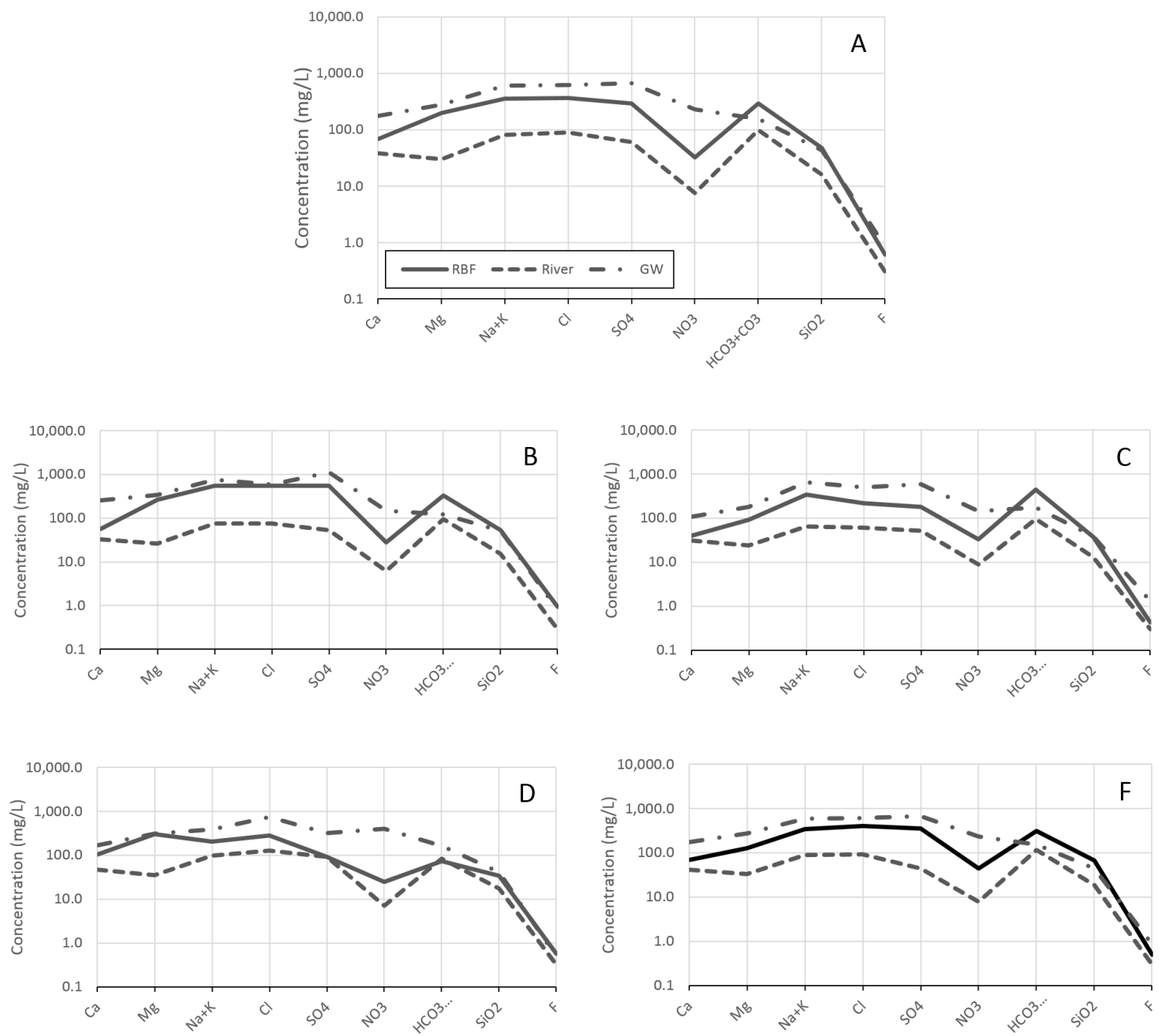

Figure 3. Major ion concentrations (mg/L) in the RBF wells (RBF, $n=52)$, the Krishna River (River, $\mathrm{n}=43$ ), and the shallow groundwater $(\mathrm{GW}, \mathrm{n}=10)$. (A) Averages across all villages, (B) Village 1, (C) Village 2, (D) Village 3, and(E) Village 4 RBF 2. No GW was analyzed in Village 3; the average GW composition was graphed instead.

A closer examination of the cation chemistry reveals that $\mathrm{Na}$ was generally the dominant cation in the RBF water, followed by $\mathrm{Mg}$ and $\mathrm{Ca}$, with $\mathrm{K}$ only a minor constituent $(\leq 3.7 \mathrm{mg} / \mathrm{L})$. In the RBF water at Village 4, Mg rather than $\mathrm{Na}$ was the dominant cation. In river water, $\mathrm{Na}$ was also the dominant cation, but $\mathrm{Ca}$ was of greater abundance relative to $\mathrm{Mg}$. Cation concentrations in shallow groundwater followed a similar pattern as RBF and river water, but they were between 1.7 and 2.6 times higher when compared to RBF water (Table S3).

Regarding anions, $\mathrm{Cl}$ generally was the dominant anion in $\mathrm{RBF}$ water, followed by $\mathrm{SO}_{4}$, and then $\mathrm{HCO}_{3}+\mathrm{CO}_{3}$. The observed application of magnesium sulfate fertilizer to sugar cane fields surrounding RBF well fields likely contributed to the high $\mathrm{SO}_{4}$ (and $\mathrm{Mg}$ ) concentrations in $\mathrm{RBF}$ water. Average $\mathrm{NO}_{3}$ concentrations ranged from 22.6 to $44.6 \mathrm{mg} / \mathrm{L}\left(\right.$ as $\mathrm{NO}_{3}$ ), while $\mathrm{F}$ was $<1 \mathrm{mg} / \mathrm{L}$. High $\mathrm{NO}_{3}$ concentrations can result from geogenic and anthropogenic sources [34]; but with $\mathrm{NO}_{3}$ leaching phyllitic and quartzite bedrock being absent, anthropogenic sources, including animal and human waste, were the likely origins of nitrate in the study area. In the Molwad RBF well, $\mathrm{HCO}_{3}+\mathrm{CO}_{3}$ surpassed $\mathrm{Cl}$ as the dominant anion. When compared to Villages 3 and $4(<0.3 \mathrm{mg} / \mathrm{L})$, the phosphate concentrations were higher in Villages 1 and 2 (up to $1.2 \mathrm{mg} / \mathrm{L}$ ), suggesting that more fertilizer was applied in these villages. As in the river, boron was found to be below the detection limit of $0.1 \mathrm{mg} / \mathrm{L}$ in all samples. 
The dissolved major ionic species milliequivalents were plotted on a Piper diagram [35] to further investigate the hydrogeochemical character of RBF water $(n=45)$ in relation to river $(n=32)$ and shallow groundwater $(n=12)$ (Figure 4$)$. The diagram indicates that $28.1 \%$ and $15.6 \%$ of the river water samples plot in the $\mathrm{Ca}-\mathrm{Mg}-\mathrm{HCO}_{3}$ (I) and $\mathrm{Na}-\mathrm{Cl}$ (III) segments, respectively, while the majority of river water samples $(56.3 \%)$ are of mixed type (Ca-Mg-Na-Cl- $\left.-\mathrm{HCO}_{3} ; \mathrm{V}\right)$. In comparison, $46.1 \%$ of RBF samples are of mixed type (Ca-Mg-Na-Cl- $\mathrm{HCO}_{3}$ ), $28.9 \% \mathrm{Na}-\mathrm{Cl}$ (III), and $25.0 \% \mathrm{Ca}-\mathrm{Mg}-\mathrm{Cl}$ (II). At Village 1, the RBF water had a strong $(62.5 \%) \mathrm{Na}-\mathrm{Ca}-\mathrm{HCO}_{3}-\mathrm{Cl}(\mathrm{VI})$ signature, setting this water apart from all other RBF sites. Shallow groundwater samples are a mixture of $\mathrm{Ca}-\mathrm{Mg}-\mathrm{Cl}$ (II), $\mathrm{Na}-\mathrm{Cl}$ (III), and Cal-Mg-Cl- $\mathrm{HCO}_{3}(\mathrm{~V})$ types. Overall, the hydrogeochemical signatures of the $\mathrm{RBF}$ water at all sites, except Village 1, have the characteristics of predominantly mixed-type river and $\mathrm{Na}-\mathrm{Cl} / \mathrm{Mg}-\mathrm{SO}_{4}$ type groundwater. The unique hydrogeochemistry of the RBF water at Village 1 suggests that local conditions, such as inflow of Na-bicarbonate rich water typically found in deeper portions of aquifers, must be considered.

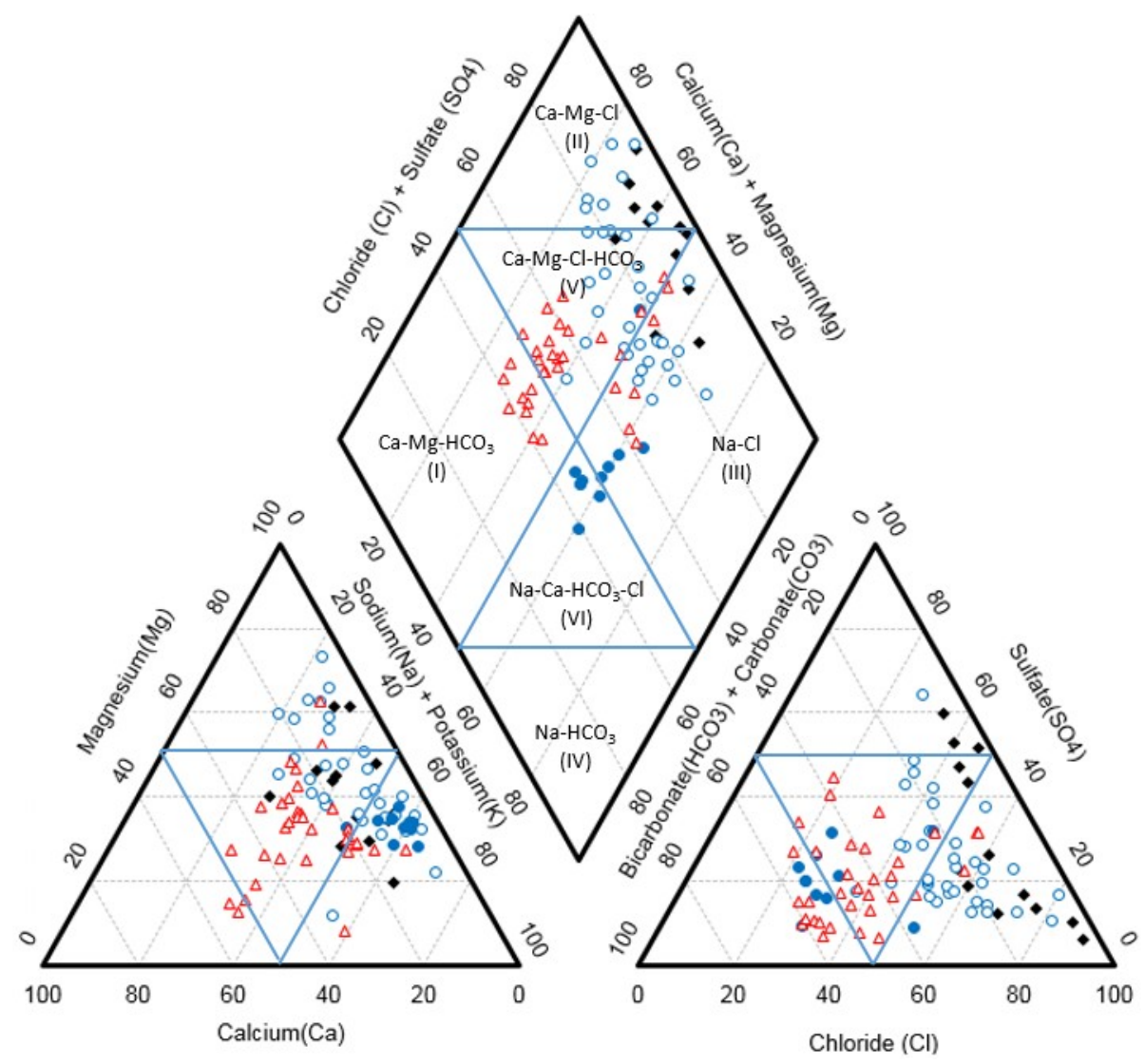

Figure 4. Piper diagram showing the hydrogeochemical character of the RBF water in comparison to the river and groundwater. Red triangles: River, Open blue circles: RBF, Bold blue circles: RBF in Village 1, Black diamonds: Groundwater.

In summary, the water quality results show that $E$. coli and turbidity values were lower in the RBF wells as compared with the Krishna River. While RBF water was highly mineralized relative to the river year-round, it was not as saline as the local shallow groundwater. Still, most major ion concentrations (magnesium, chloride, and sulfate, in particular) in RBF water exceeded the recommended BIS drinking water limits.

\subsection{Well Field Hydraulics}

A continuously pumped RBF well is expected to achieve the strongest hydraulic connection to the nearby river. Therefore, it must be expected that an intermittent power supply negatively impacts RBF 
water quality, because flow from the river to the well is interrupted during power outages, leading to a higher fraction of higher mineralized groundwater entering the well when pumping resumes. To investigate the impact of intermittent versus continuous pumping on RBF water quality, the pump in the RBF2 well in Village 4 was temporarily connected to a continuous electricity supply (diesel electric generator) and was pumped continuously for 11 days in September/October 2017. During the test, chloride and nitrate concentrations decreased by $6.2 \%$ and $16.2 \%$, respectively (Figure 5). Additionally, the concentrations were lower (9\% to $15 \%$ in the case of chloride, and 33\% to $43 \%$ for nitrate) when compared to samples that were collected immediately before and after the test when pumping was intermittent. However, no corresponding changes were observed for other major ions, TDS, or EC. Hence, the pumping test did not conclusively answer whether a continuous power supply and a longer pumping duration or higher pumping rate could have increased the portion of bank filtrate in the pumped water, thereby enhancing the water quality in the RBF well.

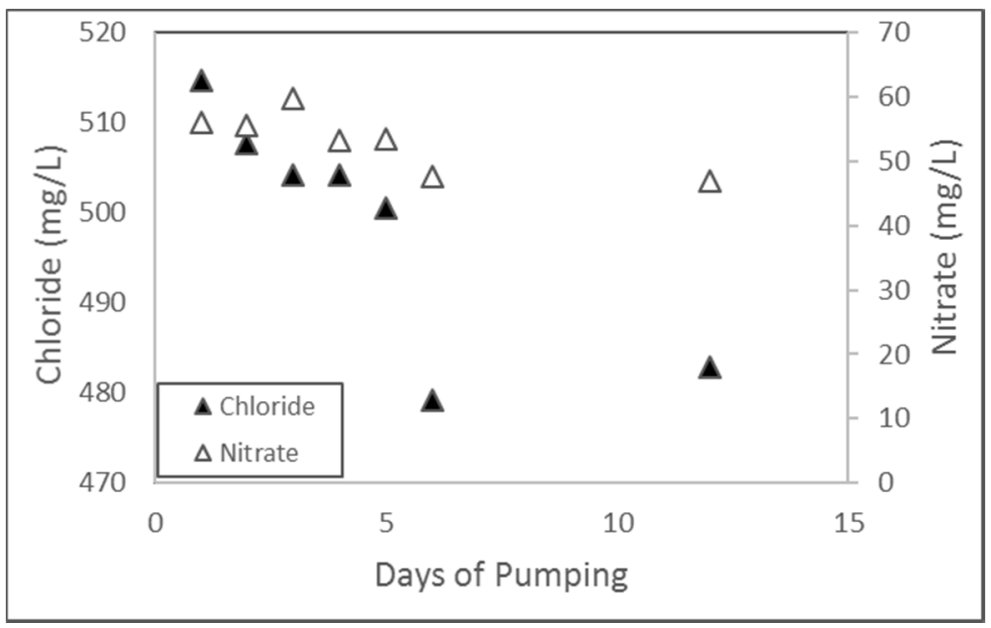

Figure 5. Chloride and nitrate concentrations decreased during continuous pumping of RBF2 well at Village 4.

In addition to continuous pumping, it was investigated if the well water quality, measured as EC, changed with depth. The assumption was that lower EC values that are associated with inflow of river water dominates at shallower depth, whereas higher EC values, which is water containing higher TDS loads, indicate the inflow of water from deeper parts of the aquifer. This kind of vertical stratification was previously reported for a well field located in southern India (Goa) [36]. The data show that the EC did indeed increase with depth, i.e. form approximately $3000 \mu \mathrm{S} / \mathrm{cm}$ to $3800 \mu \mathrm{S} / \mathrm{cm}$ (Figure S2). The EC in the upper part of the water column was 0.77 times lower than in the deeper part. That is, comparatively lower EC values coincided with the alluvial sediments (sand and medium gravel) that were encountered during well drilling 5.5 to $11 \mathrm{~m}$ below the water table, while a distinct jump in EC was observed between $11 \mathrm{~m}$ and $14 \mathrm{~m}$ below the water table. This depth coincided with the fractured bedrock depth. The vertical EC profile data suggests that river water with comparatively low EC $(699 \mu \mathrm{S} / \mathrm{cm}$ at time of test) contributed to the RBF well.

The magnitude of the contribution of river water versus groundwater to a RBF well can be estimated from mixing calculations (Equation (1)), where the percentage of river water contribution to the RBF well is equal to:

$$
\% \text { River }=\frac{\left(C_{R B F}-C_{G W}\right)}{\left(C_{R}-C_{G W}\right)}
$$

where $C_{R B F}, C_{R}$, and $C_{G W}$ are the concentrations of a compound in the RBF well water, the river, and the groundwater, respectively. Equation (1) was solved for the dominating ions ( $\mathrm{Na}, \mathrm{Mg}$, and $\mathrm{Cl}$ ) and EC, using field data collected in mid-February 2018. On that date, concurrent samples were collected from all three water sources (groundwater, RBF, and river), except at Village 3, where no GW wells 
were available for sampling in the vicinity of the RBF well. It is noted that all wells were installed along fairly straight, gaining sections of the river, as opposed to areas inside a meander where the groundwater flow towards a RBF well would be less important (See Figure 1).

The RBF wells in Villages 1 and 4 received between $40 \%$ and $74 \%$ (estimated) river water at the time of testing. At Village 2, the mixing percentage was $15 \%$ and $0 \%$ in terms EC and ion concentrations, respectively. That data set in Table 4 suggests a prevalence of groundwater flow to the RBF well and minimal river water mixing.

Table 4. Contribution (\%) of river water to RBF well water based on mixing ratios from ion, dissolved silica, and electric conductivity (EC) measurements. Note: Both RBF wells at Village 1 were lumped together because of their proximity.

\begin{tabular}{cccccc}
\hline Village & Mg & Na & Cl & EC & Average \\
\hline Village 1 & $84 \%$ & $62 \%$ & $80 \%$ & $68 \%$ & $74 \%$ \\
Village 2 & $0 \%$ & $0 \%$ & $0 \%$ & $15 \%$ & $4 \%$ \\
Village 4 RBF1 & $61 \%$ & $47 \%$ & $68 \%$ & $69 \%$ & $61 \%$ \\
Village 4 RBF2 & $36 \%$ & $34 \%$ & $48 \%$ & $42 \%$ & $40 \%$ \\
\hline
\end{tabular}

There was no apparent correlation between the degree of mixing and the local geology, i.e., RBF wells installed in sand-rich alluvial sediments at Village 4 RBF 2 did not draw-in more river water than wells that there were installed in less permeable, more silty deposits, such as Village 4 RBF 1. However, the well with the highest river water contribution (Village 1) was also the RBF well that was installed closest to the river $(22 \mathrm{~m}$; Table 1$)$. This observation suggests that the setback distance from the river was of greater significance than the presence of more permeable deposits along this part of the Krishna River. This assessment is further supported by data from Village 2, where the geology was similar to Village 1, but where the set-back distance was greater, resulting in the lowest mixing ratio of all sites. Further, the comparative close vicinity of the groundwater wells (less than $180 \mathrm{~m}$ from RBF wells) and their similar depth (36.5 m or less) suggest that possible influences of location, well depth, or other boundary conditions on the mixing calculations were minimal.

Since the mixing calculations were based on only one sampling campaign (February 2018) and a limited number of samples from groundwater wells (handpumps/boreholes; $n=12$ ), it was not possible to evaluate whether these ratios changed throughout the season. However, higher river water contributions should be expected during and after the monsoon when the Krishna River stage is high. Conversely, lower contributions are likely towards the height of the dry season (April to June), when the flow of water in river at its lowest.

\section{Conclusions}

The results of this study provide evidence that RBF installations are challenging but possible under the climate and hydrogeologic conditions prevailing in this part of southern India, where there is generally a lack of the typically thick, highly conductive alluvial sediments that are more common along the major rivers of northern India, such as the Ganga or Yamuna [14].

In this study, RBF well fields were installed at four sites along the upper Krishna River watershed and water quality and quantity studies were performed to characterize the RBF systems operation. RBF water treatment resulted in expected reductions in E. coli and turbidity, even though the RBF well setback distances from the river were less than what is considered to be typical for RBF sites in northern India, i.e., $50 \mathrm{~m}$ or more [14]. However, RBF treatment performance was hindered by the overall suboptimal hydraulic and hydrogeochemical conditions in combination with highly saline shallow groundwater in the study area.

Although the sediments that were encountered at the Krishna River study sites were less permeable than those typically observed in northern India, the data confirm that RBF well yields in this setting are sufficient to supply populations of 2000 to 3000 . However, appropriate site selection 
is critical, and when installing RBF wells one needs to balance the well depth and set-back distance from the river against the presence and composition of alluvial deposits. This can be difficult because geologic and hydrogeologic conditions along major rivers in this part of southern India appear to be more variable and often less supportive for RBF. The viability of RBF systems as a domestic water source is also influenced by other factors not limited to southern India, including surface water and groundwater salinity, agricultural practices in the vicinity of RBF wells, and the reliability of the power grid.

Identifying appropriate RBF sites in this part of southern India will remain challenging until more detailed hydrogeological data become available. To aid in the installation of future RBF systems, a better characterization of local groundwater quality, more detailed mapping of alluvial sediments along the river, enhancements of electrical power supply (e.g., introduction of solar or other renewable energy sources), and access to more suitable sites is required. Also, additional studies along other rivers in south India, ideally in combination with simulations of groundwater flow conditions, would be required to obtain a better understanding of RBF performance in this part of India.

Supplementary Materials: The following are available online at http:/ /www.mdpi.com/2073-4441/11/1/12/s1, Figure S1: RBF well in Village 3 during logger data retrieval by co-author Mrs. K. Patil (Source: T. Boving), Figure S2: Vertical EC profile measured in RBF2 well at Village 4 in relation to the geologic profile and the well construction diagram. Reference level: Water table. At this location, the depth from the surface to the water table was $4.6 \mathrm{~m}$. The brown loam above the alluvial sediment continued to the surface, Table S1: Methods used for analysis of water samples. IS 3025-Bureau of Indian Standards (BIS) (Part 45) Method of Sampling and Test (Physical and Chemical) for Water and Wastewater (First Revision). APHA: Standard Methods for the Examination of Wastewater, America Public Health Association. Washington, DC, USA, Table S2: Water quality parameters analyzed and BIS (2012) drinking water quality standards, where available. ND = Not defined, Table S3: Sampling results for major ion concentrations in RBF wells, the Krishna River, and groundwater (mg/L). HP: Handpump, BW: Borewell. The listed data only include samples that passed quality control, Table S4: Field parameter and E. coli concentrations in RBF wells, the Krishna River, and groundwater (mg/L). EC: electrical conductivity, DO: Dissolved Oxygen, T: Temperature, HP: Handpump, BW: Borewell.

Author Contributions: Conceptualization, T.B.B., K.P., F.D., J.O., A.B.F. and K.L.; Data curation, K.P., S.F.B., S.L.M., J.O. and A.B.F.; Formal analysis, T.B.B., K.P., S.F.B., S.L.M., J.O. and K.L.; Funding acquisition, T.B.B., K.P., M.S. and K.L.; Investigation, T.B.B., K.P., F.D., S.L.M., J.O. and K.L.; Methodology, T.B.B., K.P., F.D., S.L.M., J.O., M.S., A.B.F. and K.L.; Project administration, K.P., F.D., M.S. and K.L.; Resources, K.P., F.D., J.O. and K.L.; Software, S.F.B.; Supervision, T.B.B., K.P., F.D. and K.L.; Validation, K.P., S.F.B., S.L.M. and J.O.; Visualization, T.B.B., S.L.M. and J.O.; Writing—original draft, T.B.B., S.L.M., J.O. and K.L.; Writing-review \& editing, K.P., F.D., M.S. and A.B.F.

Funding: This work was supported by an Australian National Health and Medical Research Council (NHMRC) project grant (APP1083408).

Acknowledgments: We gratefully acknowledged the help of our field assistant Mr. R.K. Vhaval. Also, we thank the villagers and their leaders for supporting our study.

Conflicts of Interest: The authors declare no conflict of interest.

\section{References}

1. CIA (Central Intelligence Agency). CIA World Fact Book-India. 2018. Available online: https:/ /www.cia. gov/library/publications/the-world-factbook/geos/in.html (accessed on 12 December 2018).

2. FAO (Food and Agriculture Organization of the United Nations). Review of World Water Resources by Country. 2003. Available online: http:/ / www.fao.org/docrep/005/Y4473E/Y4473E00.HTM (accessed on 12 December 2018).

3. WHO (World Health Organization). Global Health Observatory Country Views. 2018. Available online: http:/ / apps.who.int/gho/data/node.country.country-IND?lang=en (accessed on 12 December 2018).

4. Black, R.E. Where and why are 10 million children dying every year? Child Care Health Dev. 2003, 361, 2226-2234. [CrossRef]

5. Fan, V.Y.-M.; Mahal, A. What prevents child diarrhoea? The impacts of water supply, toilets, and hand-washing in rural India. J. Dev. Eff. 2011, 3, 340-370. [CrossRef]

6. Ray, C.; Melin, G.; Linsky, R.B. Riverbank Filtration. Improving Source Water Quality; Kluwer Academic Publishers: Dordrecht, The Netherlands, 2003. 
7. Schmidt, C.K.; Lange, F.T.; Kuehn, H.J.B. Experiences with riverbank filtration and infiltration in Germany. ResearchGate 2003. Available online: https:/ / www.researchgate.net/publication/267779083_Experiences_ with_riverbank_filtration_and_infiltration_in_Germany (accessed on 12 December 2018).

8. Grischek, T.; Schoenheinz, D.; Ray, C. Siting and Design Issues for Riverbank Filtration Schemes. In Riverbank Filtration; Ray, C., Melin, G., Linsky, R.B., Eds.; Kluwer Academic Publishers: Dordrecht, the Netherlands, 2003; Volume 43, pp. 291-302.

9. Hiscock, K.M.; Grischek, T. Attenuation of groundwater pollution by bank filtration. J. Hydrol. 2002, 266, 139-144. [CrossRef]

10. Cady, P.; Boving, T.B.; Choudri, B.S.; Cording, A.; Patil, K.; Reddy, V. Attenuation of Bacteria at a Riverbank Filtration Site in Rural India. Water Environ. Res. 2013, 85, 2164-2174. [CrossRef]

11. Kelly, B.P.; Rydlund, J.; Paul, H. Water-Quality Changes Caused by Riverbank Filtration between the Missouri River and Three Pumping Wells of the Independence, Missouri, Well Field 2003-05. 2006; 48p. Available online: http:/ / purl.access.gpo.gov/GPO/LPS75695 (accessed on 12 December 2018).

12. Kumar, P.; Mehrotra, I. Riverbank Filtration for Water Supply: Indian Experience. In World Environmental and Water Resources Congress; American Society of Civil Engineers: Reston, VA, USA, 2009.

13. Schubert, J. Hydraulic aspects of riverbank filtration-Field studies. J. Hydrol. 2002, 266, 145-161. [CrossRef]

14. Sandhu, C.; Grischek, T.; Kumar, P.; Ray, C. Potential for Riverbank filtration in India. Clean Technol. Environ. Policy 2011, 13, 295-316. [CrossRef]

15. Boving, T.B.; Choudri, B.S.; Cady, P.; Cording, A.; Patil, K.; Reddy, V. Hydraulic and Hydrogeochemical Characteristics of a Riverbank Filtration Site in Rural India. Water Environ. Res. 2014, 86, 636-648. [CrossRef] [PubMed]

16. Mukherjee, A.; Saha, D.; Harvey, C.F.; Taylor, R.G.; Ahmed, K.M.; Bhanja, S.N. Groundwater systems of the Indian Sub-Continent. J. Hydrol. Reg. Stud. 2015, 4, 1-14. [CrossRef]

17. MIT. Electrodialysis, powered by solar panels, could provide drinking water for villages in India. Membr. Technol. 2014, 2014, 9-10. [CrossRef]

18. Census. Census of 2011; Office of the Registrar General \& Census Commissioner: New Delhi, India, 2011.

19. GoK (Government of Karnataka). District Geological Survey Report of Belagavi District; Government of Karnataka: Bangalore, India, 2017.

20. GoI (Government of India). Groundwater Information Booklet. Belgaum District; Ministry of Water Resources, Central Ground Water Board, Government of India: Bangalore, India, 2012.

21. CGWB (Central Ground Water Board). Aquifer Systems of Karnataka; Central Ground Water Board, Ministry of Water Resources, Government of India: Bangalore, India, 2012.

22. ITT (Institute for Transformative Technologies). Technology Breakthroughs for Global Water Security: A Deep Dive into South Asia; Institute for Transformative Technologies: Mumbai, India, 2018.

23. The Hans India. River Krishna among the Highly Polluted Rivers. 2016. Available online: http:/ / www.thehansindia.com/posts/index/Andhra-Pradesh/2016-07-19/River-Krishna-amongthe-highly-polluted-rivers/243080 (accessed on 12 December 2018).

24. MITRA (Maharashtra Pollution Control Board). Comprehensive Study Report on Krishna River Stretch; Maharashtra Pollution Control Board: Mumbai, India, 2014.

25. Purandara, B.K. Groundwater Quality Studies in the Belgaum District. CS/AR-2999-2000. 2000. Available online: http:/ / www.indiawaterportal.org/sites/indiawaterportal.org/files/Groundwater\%20Qulaity\% 20Studies\%20in\%20Belgaum\%20District\%20_NIH_1999-2000.pdf (accessed on 12 December 2018).

26. AWWA (American Water Works Association). Disinfection of Water Storage Facilities; AWWA C652-11; American Water Works Association: Denver, CO, USA, 2011.

27. DOH (Washington Department of Health). Emergency Disinfection of Small Water Systems; DOH 331-242; Washington Department of Health: Washington, DC, USA, 2018.

28. Dichter, G. IDEXX Colilert*-18 and Quanti-Tray* Test Method for the Detection of Fecal Coliforms in Wastewater; DEXX Laboratories, Inc.: Westbrook, TX, USA, 2011.

29. Luby, S.P.; Halder, A.K.; Huda, T.M.; Unicomb, L.; Islam, M.S.; Arnold, B.F.; Johnston, R.B. Microbiological Contamination of Drinking Water Associated with Subsequent Child Diarrhea. Am. J. Trop. Med. Hyg. 2015, 93, 904-911. [CrossRef] [PubMed]

30. BIS (Bureau of Indian Standards). Indian Standard Drinking Water IS 10500:2012—Specifications; 2nd Rev.; Bureau of Indian Standards: New Delhi, India, 2012. 
31. NRDWP. National Rural Drinking Water Programme Guidelines-2013. Available online: http://www. indiaenvironmentportal.org.in/content/265047/national-rural-drinking-water-programme-guidelines / (accessed on 12 December 2018).

32. Krishan, G.; Singh, S.; Sharma, A.; Sandhu, C.; Grischek, T.; Gosh, N.C.; Gurjar, S.; Kumar, S.; Singh, R.P.; Glorian, H.; et al. Assessment of Water Quality for River Bank Filtration along Yamuna River in Agra and Mathura. Int. J. Environ. Sci. 2016, 7, 56-67.

33. Brouwer, C.; Goffeau, A.; Heibleom, M. Introduction to Irrigation. Irrigation Water Management: Training Manual No. 1; FAO: Rome, Italy, 1985.

34. Gupta, A.; Ronghang, M.; Kumar, P.; Mehrotra, I.; Kumar, S.; Grischek, T.; Sandhu, C.; Knoeller, K. Nitrate contamination of riverbank filtrate at Srinagar, Uttarakhand, India: A case of geogenic mineralization. J. Hydrol. 2015, 531, 626-637. [CrossRef]

35. Piper, A.M. A graphic procedure in the geochemical interpretation of water-analyses. Trans. Am. Geophys. Union 1944, 25, 914. [CrossRef]

36. Boving, T.B.; Patil, K. Riverbank Filtration at the Nexus of Water-Energy-Food. In Water-Energy-Food Nexus: Principles and Practices (Geophysical Monograph Series); Chp. 18; AGU: Washington, DC, USA; Wiley: Hoboken, NJ, USA, 2017.

(C) 2018 by the authors. Licensee MDPI, Basel, Switzerland. This article is an open access article distributed under the terms and conditions of the Creative Commons Attribution (CC BY) license (http://creativecommons.org/licenses/by/4.0/). 